\title{
ANALYSIS OF POTENTIAL DRUGS INTERACTION ON ANTIHYPERTENSION DRUGS PRESCRIPTION IN COMMUNITY HEALTH CENTER OF SUKMAJAYA DISTRICT IN PERIOD OF JUNE-NOVEMBER 2015
}

\author{
ATIKA WAHYU PUSPITASARI*, AZIZAHWATI AZIZAHWATI, AYU RAHMAWATI HIDAYAT
}

Department of Clinical Pharmacy, Faculty of Pharmacy, Universitas Indonesia, Depok, Indonesia. Email: atikawahyu@farmasi.ui.ac.id Received: 20 April 2017, Revised and Accepted: 27 July 2017

\section{ABSTRACT}

Objectives: Hypertension is a common disease around the world. Depending on the severity or the presence of other diseases, whether related or unrelated, additional drug therapy may be required to optimize treatment and to reduce the side effects of drugs. The use of drugs in large amounts may increase the risk of drug interactions. The purpose of this research was to evaluate the characteristics of hypertension patients, prescriptions, and potential drug interactions in hypertensive patients in the Sukmajaya Community Health Center from June to November 2015.

Methods: This research used a descriptive analytic method and the data were retrospectively obtained.

Results: The results were based on the analysis of 350 prescriptions of female (67.43\%) and male (32.57\%) patients, with the highest prevalence of hypertension occurring at the age of $\geq 55$ years. Potential drug interactions were analyzed using Micromedex. The most frequent potential interaction resulted from the combined use of captopril and non-steroidal anti-inflammatory drugs. The most frequent mechanism of drug interaction was pharmacokinetics (51.06\%). The chi-square test results showed a significant relationship between the number of prescribed drugs and potential interactions at a probability value of 0.0001 and an odds ratio of 5.940 (15.588-2.263).

Conclusions: With respect to interaction mechanism, pharmacokinetic (51.06\%) was the most frequent and 61.70\% of potential cases involved a moderate interaction risk.

Keywords: Antihypertensive, Potential drug interactions, Prescription.

(C) 2017 The Authors. Published by Innovare Academic Sciences Pvt Ltd.This is an open access article under the CC BY license (http://creativecommons. org/licenses/by/4. 0/) DOI: http://dx.doi.org/10.22159/ajpcr.2017.v10s5.23098

\section{INTRODUCTION}

Drug interactions may occur if the effects of one drug are altered by the presence of other drugs, herbal medicines, foods, beverages, or some chemicals [1]. The prevalence of drug interactions as a whole can reach 50-60\% cases [2]. Basic-Vra et al.'s (2010) study of potential drug interactions analysis found a $51 \%$ prevalence of antihypertensive drug interaction cases, of which $60.9 \%$ involved pharmacodynamics mechanisms. In addition, studies in Indonesia on potential interactions between antihypertensive and other drugs in hypertensive patients in one community health center in Medan, found that $79.57 \%$ of drug combinations could potentially lead to drug interactions, including $45.71 \%$ of high severity [3].

Hypertension is the most prevalent non-infectious disease in Depok, affecting $53.9 \%$ of local population and representing 19,725 cases in 2013. This disease is the most commonly treated one in community health centers, especially in the age group of 45-75 years [4].

Therefore, based on this context, the authors of the present study aimed to analyze potential drug interactions with antihypertensive drugs prescribed in the Sukmajaya Community Health Center in Depok. This study is expected to contribute toward description of potential drug interactions with antihypertensive drugs and to serve as a reference for prescribing antihypertensive drugs in the Sukmajaya Community Health Center in Depok.

\section{METHODS}

Adescriptive-analytic study was performed using a cross-sectionalmethod. All data used in this study was secondary, that is, antihypertensive drug prescription records were retrospectively taken and analyzed from June to
November 2015. This study was conducted at the Sukmajaya Community Health Center from February to April 2016. The samples included antihypertensive drug prescriptions that met the inclusion criteria. The inclusion criteria are drug prescriptions containing antihypertensive drugs consisting of two or more drugs and the age of hypertensive patients $\geq 18$ years. The sampling technique was proportionate stratified random sampling. This study samples were processed and analyzed using Micromedex®. Univariate analyses were performed to determine the number and type of drugs in a prescription, patient gender and age, potential drug interactions, and the mechanism of drug interaction as well as the potential degree of drug interaction severity.

\section{RESULTS AND DISCUSSION}

\section{Subjects and population}

Of the antihypertensive drug prescription data considered from June to November 2015, 2,741 prescriptions met the inclusion criteria. The number of samples examined based on the sample calculation was 350 prescriptions (Tables 1-3).

\section{Overview of patient gender and age}

The results of this study indicate that the number of female patients who received antihypertensive drugs (67.43\%) was higher than that of male patients $(32.57 \%)$. This result is in accordance with the hypertensive prevalence report in Basic Health Survey (RISKESDAS) in Indonesia in 2007 and 2013 carried out by the National Institute of Health Research and Development, wherein it was also reported that the prevalence of hypertension is higher in female patients than in male patients [5].

Female patients are more prone to hypertension than male patients based on their etiology and pathophysiology. As an example, 
hypertension due to renal artery stenosis is more common in females than males. Other factors that cause hypertension in females are the use of oral contraceptives, pre-eclampsia, and vasculitis (inflammation of blood vessels) [6]. Furthermore, the risk of hypertension in females aged over 65 years is greater than males, and the severity of hypertension increases with increasing age [7].

This study also shows that the number of patient aged $\geq 55$ years who received antihypertensive therapy $(60.57 \%)$ is higher than patients aged $<55$ years. This result is in accordance with a previous study that obtained a hypertensive prevalence rate of $66.66 \%$ in patients aged $\geq 55$ years [8]

Patients aged $\geq 55$ years face a $90 \%$ risk of developing hypertension according to the Joint National Committee 7 [9] as a result of the aging process, which leads to decreased physiological functioning of the body and causes individuals to become more prone to cardiovascular diseases such as hypertension. Hypertension in elderly patients is generally caused by arterial stiffness, neurohormonal and autonomic dysregulation, and renal insufficiency [7]

\section{Overview of number and type of prescription drugs}

Prescriptions with $\geq 4$ types of drugs were more common (57.14\% of all prescriptions) than prescriptions with 2-3 types of drugs (42.86\% of all prescriptions). Drug combinations mostly reflected the treatment of hypertension in addition to other conditions. Other drugs prescribed beside antihypertensive drugs in the Sukmajaya Community Health Center included metformin, Vitamin B, antihistamine, antacid, paracetamol or PCT, and non-steroidal anti-inflammatory drugs (NSAIDs) such as ibuprofen, mefenamic acid, piroxicam, and diclofenac natrium.

Table 4 shows that types and combinations of prescribed antihypertension and the most prescribed drug for single prescriptions was amlodipine at Sukmajaya Community Health Center.

Amlodipine has been shown to be a well-tolerated antihypertensive drug, especially in elderly patients. Amlodipine tolerability has also been shown to be good or excellent in most patients. This is because amlodipine is slowly absorbed, and the side effects of vasodilation tend to be smaller than other CCB-group drugs. Amlodipine also has a low rate of metabolism in the liver and a longer half-life than other drugs, allowing effective blood pressure control with once-daily dosing [10].

Previous studies have also proven the effectiveness of amlodipine for decreasing blood pressure. Research conducted by Baharudin and Suwandi with 3 drugs comparation, namely, amlodipine, captopril, and

Table 1: Prescribed patients by gender

\begin{tabular}{ll}
\hline Gender & Patients n (\%) \\
\hline Male & $114(32.57)$ \\
Female & $236(67.43)$ \\
Total & $350(100)$ \\
\hline
\end{tabular}

Table 2: Prescribed patients by age

\begin{tabular}{ll}
\hline Age & Patients $\mathbf{n}(\%)$ \\
\hline$<55$ years & $138(39.43)$ \\
$\geq 55$ years & $212(60.57)$ \\
Total & $350(100)$ \\
\hline
\end{tabular}

Table 3: Number of drugs in prescriptions

\begin{tabular}{ll}
\hline Number of drugs in prescriptions & Patients $\mathbf{n}(\%)$ \\
\hline $2-3$ & $150(42.86)$ \\
$\geq 4$ & $200(57.14)$ \\
Total & $350(100)$ \\
\hline
\end{tabular}

hydrochlorothiazide (HCT). The comparation showed that amlodipine could decrease blood pressure to $32.94 / 16.38 \mathrm{mmHg}$ while captopril $(29.16 / 11.83 \mathrm{mmHg})$ and HCT $(27.05 / 9.35 \mathrm{mmHg})$ [11]. However, another study showed that amlodipine effectiveness in reaching target patient blood pressure is $100 \%$, on the other hand, captopril and HCT had lower effectiveness in decreasing patients' blood pressure in $91 \%$ and $9 \%$, respectively [12]

\section{Overview of potential drug interactions}

The analysis results from Table 5 show that of the 350 prescriptions analyzed, 39 prescriptions $(11.1 \%)$ could have resulted in potential drug interactions. These interactions were more common in prescriptions containing $\geq 4$ types of drugs. In addition, hypertension is a disease susceptible to drug interactions because they have to take their medication for lifetime and if they have other disease among their medication then the drug interaction may occur from other drug prescription [2]. These results concur with a study by Viktil et al., which concluded that a higher number of drugs taken can lead to more drug therapy problems, including drug interactions [13].

The most common antihypertensive drug interaction occurred in association with captopril (44.74\%), or in 17 cases, and with amlodipine $(26.31 \%)$, or in 10 cases. These results are in accordance with Rumanda's study on the potential interaction of antihypertensive drugs in hypertensive patients at Medan Community Health Center, highlighting a $55 \%$ interaction potential for captopril and $40.71 \%$ for amlodipine [3]

The potential drug interactions in this study were derived from the analysis of the sample prescriptions using Micromedex, and the results are further detailed at following (Tables 6 and 7).

\section{Amlodipine with simvastatin}

Amlodipine can increase the effectiveness of simvastatin by decreasing the rate of simvastatin metabolism, resulting in an increase in the maximum level, and AUC value of simvastatin. At higher doses, there is

Table 4: Types and combinations of prescribed antihypertension drugs

\begin{tabular}{ll}
\hline Antihypertension drugs & Number \\
\hline Single antihypertensive drug & \\
Amlodipine & 297 \\
Nifedipine & 6 \\
Captopril & 20 \\
Combination of 2 antihypertensive drugs & 11 \\
Amlodipine + HCT & 1 \\
Nifedipine +amlodipine & 9 \\
Amlodipine + furosemide & 1 \\
Captopril + HCT & 1 \\
Amlodipine + propranolol & \\
Combination of 3 antihypertensive drugs & 2 \\
Nifedipine + amlodipine + HCT & 1 \\
Amlodipine + furosemide + HCT & 2 \\
Nifedipine + furosemide + amlodipine & \\
\hline HCT: Hydrochlorothiazide &
\end{tabular}

Table 5: Potential drug interactions according to number of drugs in prescriptions

\begin{tabular}{|c|c|c|c|}
\hline \multirow{3}{*}{$\begin{array}{l}\text { Number of drugs } \\
\text { in prescriptions }\end{array}$} & \multicolumn{2}{|c|}{ Potential drug interactions } & \multirow{3}{*}{$\begin{array}{l}\text { Total } \\
\text { n (\%) }\end{array}$} \\
\hline & $\begin{array}{l}\text { No potential } \\
\text { interaction }\end{array}$ & $\begin{array}{l}\text { Potential } \\
\text { interaction }\end{array}$ & \\
\hline & n (\%) & n (\%) & \\
\hline $2-3$ & $145(96.7)$ & $5(3.3)$ & $150(100)$ \\
\hline$\geq 4$ & 166 (83) & $34(17)$ & $200(100)$ \\
\hline Total & 311 (88.9) & 39 (11.1) & $350(100)$ \\
\hline
\end{tabular}


a risk of myopathy, including rhabdomyolysis. Monitoring of side effects is necessary. The use of other alternative medications or any reduction in the dose of simvastatin should not exceed $20 \mathrm{mg} /$ day.

\section{Amlodipine with domperidone}

Simultaneous administration of amlodipine with domperidone can inhibit domperidone metabolism, which is mediated by CYP3A4, resulting in increased plasma concentrations of domperidone and an increased risk of QT prolongation. Case-control studies showed an increased risk of serious heart disease, including ventricular arrhythmias and sudden cardiac death, especially in domperidone doses greater than $30 \mathrm{mg} /$ day and in patients older than 60 years.

\section{Nifedipine with prednisone}

Nifedipine is metabolized by the CYP3A4 enzyme. Concomitant use with CYP3A4 inducer (prednisone) will reduce AUC and C max to about $70 \%$, so the effectiveness of nifedipine will decrease. Monitoring blood pressure is suggested. If prednisone treatment remains to be taken, then alternative antihypertensive treatments should be considered.

\section{Nifedipine with aminophylline}

The simultaneous use of nifedipine and aminophylline can alter serum aminophylline levels. Nifedipine alone cannot significantly alter antipyrine, showing that nifedipine does not affect the cytochrome P450 activity responsible for the metabolism of aminophylline. Any visible interactions between these two drugs may partly be due to competition between protein bonds.

\section{Captopril with metformin}

Captopril may affect insulin sensitivity, so combined usage with metformin may increase the hypoglycemic effect of metformin. Glucose monitoring is recommended, both during use and after captopril discharge.

\section{Captopril with glibenclamide}

Captopril may increase the glibenclamide effect through pharmacodynamics, specifically through a synergistic mechanism that increases the risk of hypoglycemia. Captopril can lower blood glucose by increasing insulin sensitivity, so the antidiabetic effect is increased and leads to greater hypoglycemic effects [14].

\section{Captopril with antacid}

Antacids may delay gastric emptying and increase the $\mathrm{pH}$ of the gastric lumen, causing a decrease in the absorption of alkaline drugs [1]. Antacid interactions with captopril may decrease captopril absorption, resulting in a reduction of captopril bioavailability to about $40 \%$. If taken together, captopril should be taken 2 hrs before antacids are given.

\section{Captopril with NSAIDs}

The NSAIDs used in this study were ibuprofen, piroxicam, and mefenamic acid. The pharmacodynamics interactions with these drugs are antagonist. NSAID drugs can reduce the effects of vasodilators due to decreased prostaglandin synthesis in the kidney, thereby affecting fluid homeostasis, reducing antihypertensive effects, and possibly leading to renal dysfunction. Interactions should be monitored,

Table 6: Potential drug interactions in antihypertensive patients

\begin{tabular}{|c|c|c|c|}
\hline Drug interactions & Severity degree & Mechanism type & n (\%) \\
\hline Amlodipine (5 mg and $10 \mathrm{mg}$ ) + simvastatin $10 \mathrm{mg}$ & Major & Pharmacokinetic & $7(14.89)$ \\
\hline Amlodipine $5 \mathrm{mg}+$ domperidone & Major & Pharmacokinetic & $3(6.38)$ \\
\hline Nifedipine $10 \mathrm{mg}+$ prednisone & Major & Pharmacokinetic & $1(2.13)$ \\
\hline Nifedipine $10 \mathrm{mg}+$ aminophylline & Minor & Pharmacokinetic & $1(2.13)$ \\
\hline Captopril 25 mg + metformin & Moderate & Pharmacodynamic & $1(2.13)$ \\
\hline Captopril (12.5 mg and $25 \mathrm{mg})+$ glibenclamide & Moderate & Pharmacodynamic & $2(4.25)$ \\
\hline Captopril (12.5 mg and $25 \mathrm{mg})+$ antacid & Moderate & Pharmacokinetic & $4(8.51)$ \\
\hline Captopril (12.5 mg and $25 \mathrm{mg})+$ piroxicam & Moderate & Pharmacodynamic & $4(8.51)$ \\
\hline Captopril $12.5 \mathrm{mg}+$ mefenamic acid & Moderate & Pharmacodynamic & $1(2.13)$ \\
\hline Captopril $25 \mathrm{mg}+$ allopurinol & Major & Unknown & $1(2.13)$ \\
\hline $\mathrm{HCT}+$ captopril $12.5 \mathrm{mg}$ & Moderate & Pharmacodynamic & $1(2.13)$ \\
\hline $\mathrm{HCT}+$ piroxicam & Moderate & Pharmacodynamic & $1(2.13)$ \\
\hline HCT + ibuprofen & Moderate & Pharmacodynamic & $1(2.13)$ \\
\hline HCT + diclofenac natrium & Moderate & Pharmacodynamic & $1(2.13)$ \\
\hline $\mathrm{HCT}+$ prednisone & Moderate & Pharmacodynamic & $1(2.13)$ \\
\hline Furosemide + diclofenac natrium & Moderate & Pharmacodynamic & $1(2.13)$ \\
\hline Ciprofloxacin + dexamethasone & Moderate & Pharmacodynamic & $1(2.13)$ \\
\hline Glibenclamide + antacid & Minor & Pharmacokinetic & $1(2.13)$ \\
\hline Antacid + mefenamic acid & Moderate & Pharmacokinetic & $3(6.38)$ \\
\hline Vitamin $\mathrm{C}+$ antacid & Minor & Pharmacokinetic & $1(2.13)$ \\
\hline Ciprofloxacin + diclofenac natrium & Moderate & Pharmacokinetic & $1(2.13)$ \\
\hline Chloramphenicol + PCT & Minor & Pharmacodynamic & $1(2.13)$ \\
\hline Domperidone + ranitidine & Major & Pharmacokinetic & $2(4.25)$ \\
\hline Total & & & $47(100)$ \\
\hline
\end{tabular}

HCT: Hydrochlorothiazide

Table 7: Frequency of potential interactions in antihypertensive patients

\begin{tabular}{llll}
\hline Antihypertensive drugs & Name of drugs & Number of times drug prescribed & Number of potential drug interactions \\
\hline Angiotensin-converting-enzyme inhibitor & Captopril & 21 & 17 \\
Beta Blocker & Propranolol & 1 & 0 \\
CCB & Amlodipine & 324 & 10 \\
Diuretic & Nifedipine & 11 & 2 \\
& HCT & 15 & 5 \\
\hline
\end{tabular}

CCB: Calcium channel blocker, HCT: Hydrochlorothiazide 
including the resulting antihypertensive effects, and kidney function should be periodically checked for signs of renal failure.

\section{Captopril with allopurinol}

The simultaneous use of captopril and allopurinol may cause hypersensitivity reactions and may also present risks for Stevens-Johnson syndrome and anaphylaxis. The interaction mechanism is unknown. However, to prevent the severity of such interactions, the hypersensitivity reaction should be monitored, and other alternatives should be used if needed.

\section{HCT with captopril}

The pharmacodynamics interaction between captopril and HCT is synergistic. The use of both captopril and HCT can simultaneously increase the effects of vasodilation and decrease the intravascular volume of blood, thus posing a risk of postural hypotension following the initial dose as well as acute hypotension and renal insufficiency. Blood pressure should be monitored during severe hypotension response for $4 \mathrm{hrs}$ after initial dose.

\section{HCT with NSAIDs}

The NSAIDs used in this study were piroxicam, ibuprofen, and diclofenac sodium. The use of HCT with NSAID drugs simultaneously can decrease the production of renal prostaglandins, thereby decreasing the diuretic and antihypertensive effects. Monitoring of blood pressure, weight gain, and signs of renal impairment is required, including decreased urinary secretions and increased edema, and treatment may be necessary to reduce the side effects of drug interactions.

\section{HCT with prednisone}

Prednisone and HCT can interact through the mechanism of additive kaliuresis, thus raising the risk of hypokalemia, primarily as a result of strong glucocorticoid activity and arrhythmias.

\section{Furosemide with NSAIDs}

NSAID drugs and furosemide are antagonistic, and their interaction may decrease the effects of furosemide. NSAID drugs can specifically decrease the synthesis of renal prostaglandins, thereby reducing the diuretic and antihypertensive effects of furosemide.

\section{Ciprofloxacin with dexamethasone}

The simultaneous combination of ciprofloxacin and dexamethasone can result in an increase in the effects of each drug. Interaction effects may increase the risk of torn tendons (ruptured tendons). Combined use should be stopped if pain or inflammation occurs in tendons.

\section{Glibenclamide with antacid}

Simultaneous use of glibenclamide and antacids may increase the rate of glibenclamide absorption, which may lead to an increase in glibenclamide effects. Blood glucose monitoring for signs of hypoglycemia and reducing the dose of glibenclamide is required based on serum blood sugar.

\section{Antacid with mefenamic acid}

Magnesium hydroxide from antacids may increase the absorption of mefenamic acid, thus increasing the risk of side effects from mefenamic acid. Monitoring of possible antacid toxicity (e.g., nausea, vomiting, or depression) and appropriate dose adjustment are required.

\section{Vitamin C with antacid}

Vitamin $\mathrm{C}$ increases antacid levels $\left(\mathrm{Al}(\mathrm{OH})_{2}\right)$ by increasing their absorption in the gastrointestinal tract, possibly resulting in antacid toxicity, including seizures and coma.

\section{Ciprofloxacin with diclofenac sodium}

The use of ciprofloxacin and diclofenac sodium simultaneously can increase plasma concentrations of ciprofloxacin.
Table 8: Frequency of potential drug interactions by interaction mechanism

\begin{tabular}{ll}
\hline Interaction mechanism & n (\%) \\
\hline Pharmacokinetic & $24(51.06)$ \\
Pharmacodynamic & $22(46.81)$ \\
Unknown & $1(2.13)$ \\
Total & $47(100)$ \\
\hline
\end{tabular}

Table 9: Frequency of potential drug interactions by severity degree

\begin{tabular}{ll}
\hline Severity degree & n (\%) \\
\hline Major & $14(29.79)$ \\
Moderate & $29(61.70)$ \\
Minor & $4(8.51)$ \\
Total & $47(100)$ \\
\hline
\end{tabular}

\section{Chloramphenicol with PCT}

The simultaneous use of chloramphenicol and PCT leads to chloramphenicol toxicity, including hypotension, hypothermia, and vomiting.

\section{Domperidone with ranitidine}

Administration of ranitidine combined with domperidone may inhibit the domperidone metabolism mediated by CYP3A4, resulting in increased plasma concentrations of domperidone. Thus, ranitidine can increase the effects of domperidone and the risk of QT prolongation. Use with caution, as ranitidine may lead to serious heart disease, including ventricular arrhythmias and sudden cardiac death, especially for domperidone doses $>30 \mathrm{mg} /$ day and in patients older than 60 years.

Frequency of interaction mechanism type and interaction severity degree

The most frequent interaction mechanism in this study was pharmacokinetic (51.06\%) (Table 8). This result concurs with Sivva et al.'s (2015) study on the assessment of drug interactions in hypertensive patients in one hospital in India, which also obtained more cases of pharmacokinetic $(62.26 \%)$ than pharmacodynamic interactions. Drugs may limit the absorption of antihypertensive agents, alter their metabolism through either enzyme inhibition or induction, or change renal excretion. Furthermore, the antihypertensive response may be produced [1].

The results of this analysis are presented in Table 9, wherein the degree of interaction severity was most frequently moderate (in $61.70 \%$ of possible cases). This result is coherent with Sivva et al.'s (2015) study in which moderate interaction cases (84.90\%) were much more common than major and minor interactions. Moderate interactions may lead to changes in patient clinical status, the need for additional treatment, or the prolongation of hospital stays [13].

\section{CONCLUSIONS}

Potential drug interactions in hypertensive patients taking antihypertensive drugs were identified in 39 prescriptions $(11.1 \%$ of all studied prescriptions), with most interaction cases resulting from the combination of captopril with NSAIDs or of amlodipine drugs with simvastatin. With respect to interaction mechanism, pharmacokinetic $(51.06 \%)$ was the most frequent and $61.70 \%$ of potential cases involved a moderate interaction risk

\section{REFERENCES}

1. Stockley IH. Stockley's Drug Interactions. $8^{\text {th }}$ ed. London: The Pharmaceutical Press; 2008.

2. Syamsudin. Interaksi Obat: Konsep Dasar dan Klinis. Jakarta: Penerbit Universitas Indonesia (UI-Press); 2011

3. Rumanda N. Potensi Interaksi Obat Antihipertensi pada Pasien 
Hipertensi di Puskesmas di Kota Medan. Medan: Fakultas Farmasi Universitas Sumatera Utara; 2015.

4. Dinas Kesehatan Kota Depok. Profil Kesehatan Kota Depok Tahun 2013. Depok: Dinas Kesehatan Kota Depok; 2013.

5. Pusat Data dan Informasi Kementerian Kesehatan RI. Info Datin Hipertensi. Jakarta: Pusat Data dan Informasi Kementerian Kesehatan RI; 2014.

6. Igho Pemu P, Ofili E. Hypertension in women: Part I. J Clin Hypertens (Greenwich) 2008;10(5):406-10.

7. Lionakis N, Mendrinos D, Sanidas E, Favatas G, Georgopoulou M. Hypertension in the elderly. World J Cardiol 2012;4(5):135-47.

8. Sumawa PM, Wulllur AC, Yamlean PV. Evaluation on the rationality of the use of anti-hypertensive drugs on hypertension in-patients of Prof. DR. R. D. Kandou Hospital, Manado during January-June 2014. J Ilmiah Farmasi 2015;4(3):2302-493.

9. Department of Health and Human Services. The Seventh Report of the Joint National Commite on Prevention, Detection, Evaluation, and Treatment of High Blood Pressure. United State: Department of Health and Human Services; 2004.

10. Pascual J. Hypertension control in the elderly with amlodipine. Curr Med Res Opin 2000;16(1):33-6.

11. Baharudin KP, Suwandi D. Perbandingan Efektivitas dan Efek Samping Obat Antihipertensi Terhadap Penurunan Tekanan Darah Pasien Hipertensi. Sulawesi Selatan: Fakultas Kedokteran Universitas Hasanudin; 2013.

12. Kristanti P. Effectiveness and Side Effects of Anti-hypertensive Medication Usage in Hypertension Patients at Kalirungkut Public Health Center,Surabaya. Jurnal Ilmiah Mahasiswa Universitas Surabaya 2015;4(2):4

13. Viktil KK, Blix HS, Moger TA, Reikvam A. Polypharmacy as commonly defined is an indicator of limited value in the assessment of drug-related problems. Br J Clin Pharmacol 2007;63(2):187-95.

14. Arauz-Pacheco C, Ramirez LC, Rios JM, Raskin P. Hypoglycemia induced by angiotensin-converting enzyme inhibitors in patients with non-insulin-dependent diabetes receiving sulfonylurea therapy. Am J Med 1990;89(6):811-3. 